\title{
Self-Regulated Learning and Technology-Enhanced Learning Environments in Higher Education: A Scoping Review
}

\author{
Santos Urbina *, Sofía Villatoro (D) and Jesús Salinas \\ Institute for Educational Research and Innovation, University of the Balearic Islands, 07122 Palma, Spain; \\ sofia.villatoro@uib.es (S.V.); jesus.salinas@uib.es (J.S.) \\ * Correspondence: santos.urbina@uib.es; Tel.: +34-971-17-2842
}

check for updates

Citation: Urbina, S.; Villatoro, S.;

Salinas, J. Self-Regulated Learning and Technology-Enhanced Learning Environments in Higher Education: A Scoping Review. Sustainability 2021, 13, 7281. https://doi.org/10.3390/ su13137281

Academic Editor: Daniel Burgos

Received: 1 June 2021

Accepted: 23 June 2021

Published: 29 June 2021

Publisher's Note: MDPI stays neutral with regard to jurisdictional claims in published maps and institutional affiliations.

Copyright: (c) 2021 by the authors. Licensee MDPI, Basel, Switzerland. This article is an open access article distributed under the terms and conditions of the Creative Commons Attribution (CC BY) license (https:/ / creativecommons.org/licenses/by/ $4.0 /)$.

\begin{abstract}
This paper seeks to identify the characteristics of studies of self-regulated learning that consider the use of technology-enriched environments in higher education. To this end, a review was conducted of the scientific literature during the period 2015-2021 in various scientific databases. The analysis identified 42 research papers that met the inclusion and exclusion criteria. The results show that this topic has been gaining interest among researchers and the main strategies developed to self-regulate students in academic virtual environments. On the other hand, classical self-regulated learning models underpin most of the studies reviewed; Zimmermann's approaches, or those derived from his work, are the most frequent. As regards the methodology adopted, the preferred focus is quantitative; the questionnaire is the most used for data collection. Most of the research was carried out with students studying for different university degrees; the most-analysed technology tools were LMS platforms.
\end{abstract}

Keywords: self-regulated learning; ICT; technology-enhanced learning environments; scoping review

\section{Introduction}

The concept that students are active agents that have become the centre of the teachinglearning process is a powerful idea in research related to educational technology. In technology-enriched learning environments, one of the keys to achieving learning goals lies in the autonomous management of a skill set that contributes to such an achievement. This is a set of transferable skills that are usually related to the concept of self-regulated learning (SRL). The concern lies in the student controlling his/her own learning process, a topic that began to be researched in the mid-1980s [1].

Carneiro et al. [2] differentiated between two forms of the concept of self-regulated learning: one, which is more restrictive, refers to the self-regulation of learning processes by the student himself/herself to carry out a given task (where more didactic strategies would come into play in formal educational contexts), oriented, therefore, at autonomy in the process; and another, broader one is equivalent to self-directed learning and refers to taking the initiative and responsibility in selecting, managing and assessing their own learning activities, which may occur at any time, place, age and through any means (which may include informal learning processes), oriented more at learning to learn [3-5].

The purpose of this study was to seek models that will contribute to representing aspects of self-regulated learning in technology-enhanced learning environments, especially in the second sense. Classical works on self-regulated learning by Zimmermann and others [6-13] have given rise to various models for representing self-regulated learning but only where technology was not yet a consideration. Among them, those by Zimmerman [14] and Pintrich [9] may be considered leading studies and have strongly influenced later ones. Both models are based on socio-cognitive postulates, and both of them explain self-regulated learning as a cyclical process, influenced by context, where the process is organized into phases in which cognitive, meta-cognitive and motivational strategies are selected and combined but always in conventional environments. 
The interest in studying aspects of autonomous learning that began in the 1980s crystallised into a research trend focused on self-regulation and from which several various models inspired by various theoretical approaches arose [15]. Papers on self-regulated learning based on Bandura's socio-cognitive theory have had the greatest impact, and of all of them, those by Zimmerman [14] and Pintrich [9] are the most widely used, especially regarding early educational stages.

These models share certain characteristics: self-sufficiency is an essential variable for both models; the presence of a feedback or review model in which the students control the learning methods and strategies or the reasons why students choose a certain strategy during the self-regulation process are others $[15,16]$. However, they also show certain differences: while Zimmerman's model [14] shows greater explanatory power and has been the predominant model in research in the field of education when working with teachers, the model proposed by Pintrich [9] includes the link between the cognitive and affective-motivational factors that come into play during the learning process or highlight the influence of the social context in which it takes place.

The conceptual complexity the self-regulated learning construct offers has stimulated recent research into self-regulation of learning and about the models developed to explain it in the information and knowledge society. One of the most comprehensive studies was by Panadero [15]; it analysed and compared six models according to their implications for education: Zimmerman; Boekaerts; Winne and Hadwin; Pintrich; Efklides; and that by Hadwin, Järvelä and Miller.

However, it would be desirable to be able to determine to what extent technologyenriched environments can foster the development of self-regulated learning. We therefore believe it is of interest to offer an overview of recent research around this topic by analysing the scientific literature in the form of a scoping review.

In the current university context, competency-based assessment aims to enable students to be competent in the use of technological tools in their future professional performance in a sustainable manner.

These skills, in the world of work, are essential for coping with lifelong learning. Based on this idea, it is necessary that students learn to self-regulate in educational processes, acquiring sustainable and long-lasting habits.

This paper aims to contribute to the identification and description of the scientific literature on this topic in order to provide a starting point for other interested researchers.

\section{Method}

\subsection{Search Sources}

The search terms were identified from scientific papers, both in English and in Spanish, using various Boolean operators in databases to review the literature. The sources selected are those listed below, given their significance in the field of educational research: EBSCOhost, Web of Science, Scopus, ERIC and Dialnet. The search was restricted to the years 2015-2021.

The descriptors used were: (self-regulat* OR "self regulat") AND learning AND (techno* OR comput*). Although this review focuses on studies of "technology-enriched learning environments" (TELE), we consider it preferable to use the terms derived from "technology" and "computer", since they have been more extensively used and show greater stability over the time period adopted.

\subsection{Inclusion Criteria}

The criteria used in the search are specified in Table 1. Subsequently, in Figure 1, the application of the criteria can be verified until the final sample is reached. 
Table 1. Specification of the inclusion criteria.

Inclusion Criteria
Years of publication. Articles included in the period 2015-2021.
Type of document. Research papers are included.
The topic encompasses the aims of the review.
The topic of the document refers to the self-regulation of learning.
The use of technological tools promotes self-regulation.
The population in which the research is undertaken is a university population.
Technology as an educational resource is a cornerstone of the research.

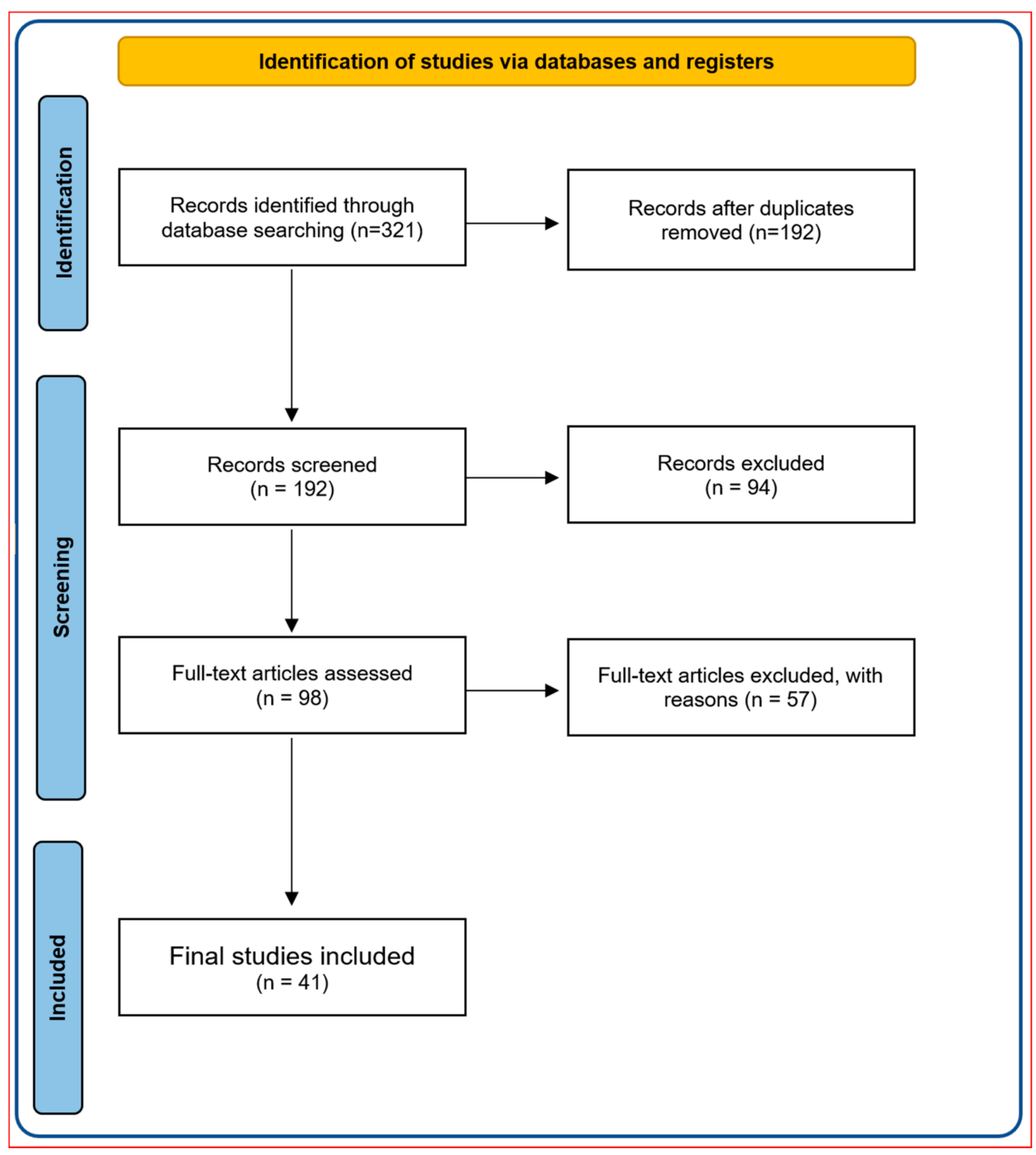

Figure 1. Search process.

\subsection{Limits and Methodology of the Search}

As has already been mentioned, the methodology adopted in this paper is a scoping review. According to Pharm et al. [17], the purpose of a scoping review is to offer a map or overview of the literature on a broad topic, without the need to carry out an extensive review of data. 
This type of review has multiple uses, making it possible, among other things, to reveal the need for future systematic reviews [18], as well as being useful for researchers and professionals, offering, moreover, a guide for research [19].

Scoping reviews share with systematic reviews their rigour and their use of transparent methods to identify and analyse the relevant aspects of the literature with respect to a topic of interest $[17,19]$. However, a scoping review is broader in its coverage than a systematic review, which seeks to compile evidence from a smaller number of studies $[17,18]$.

As set out by the authors Armstrong et al. [19], a scoping review can serve to: explore the scope of the literature in a given field, without describing the findings in detail; help to identify the appropriate parameters of a review; and identify the possibilities of undertaking a systematic review, considering its cost.

This study was based on the model generated by the Joanna Briggs Institute [20] which contains the following phases in preparing a scoping review: defining the aims and questions; developing and listing the inclusion criteria with the aims and questions; a description of the proposed focus for the search for evidence, selection, extraction and graphics; search for evidence; selection of evidence; extraction of evidence; presentation of the evidence in graphic form; summary of the evidence in relation to the aims and question; and consultation with experts in documentation and libraries (over the course of the process).

Research questions:

- What are the characteristics of SRL researches who consider the use of TechnologyEnhanced Learning Environments (TELE) in higher education contexts?

- Is there some area of knowledge where this type of studies is of greater interest?

- Is there some type of methodological focus that is adopted by preference?

- What technological elements have been the main focus of the research undertaken?

General objective:

To identify the characteristics of studies of SRL that consider use of TELE in higher education contexts.

Specific objectives:

- To identify the areas of knowledge where the selected studies have been carried out;

- To know the methodological approaches adopted;

- To determine the technological environments being studied.

\subsection{Procedure}

The review was carried out in different phases until it reached the end result. Initially, a total of 321 studies were identified that matched the search criteria set. Thereafter, the articles that were duplicated, due to being included in different databases used, were discarded, leaving a total of 192. This number was reduced to 98 after discarding those studies that, after a superficial review, did not mention self-regulation models or ICT or because the topic was not related to education (94). After reading them in depth, a further 57 articles were excluded for various reasons (not focusing on the university sector or not having a topic of study that fully matches the criteria adopted), which in the end reduced the number to 41 .

In the following diagram, prepared according to the PRISMA model (Figure 1), we can see the process followed in searching for and refining the selected articles, according to Mother et al. [21].

To examine the data, a protocol was used that made it possible to organise the characteristics of each article. The analysis protocol collected information in the following fields: (1) title; (2) authors; (3) year of publication; (4) framework and reference model; (5) phases of self-regulation; (6) elements; (7) ICT strategies to promote self-regulation.

The following tools were then used to extract and organise the data: 
- Rayyan QCRI. Article dumping and classification by inclusion or exclusion criteria using tags.

- Airtable. To make a database of articles and extraction of the most important aspects.

According to the results that fulfil the inclusion criteria, a table was prepared based on the items in the protocol provided for analysing the data.

The models refer to the theoretical framework underpinning the reviewed research. The phases are the different milestones involved in the self-regulation of learning. On the other hand, during the process, we may identify a series of technological elements and strategies that may serve to help the student.

As mentioned above, the aims of the papers analysed are based on promoting selfregulation of learning in relation to ICT.

\section{Results and Discussion}

\subsection{Selection, Extraction and Presentation in Graphic Form of the Evidence}

This section answers the different research questions and analyses additional aspects of interest.

\subsubsection{Years of Publication of the Evidence Selected}

Below are 41 papers from the selected sample (Table 2), in table form and ordered chronologically. The search was made in December 2020 (although some publications from 2021 were already accessible, one of which was included in the end).

Table 2. Identification of studies by year of publication.

\begin{tabular}{ccc}
\hline Year of Publication & Reference & $n$ \\
\hline 2015 & {$[22,23]$} & $(n=2)$ \\
2016 & {$[24-31]$} & $(n=8)$ \\
2017 & {$[32-37]$} & $(n=6)$ \\
2018 & {$[38-46]$} & $(n=9)$ \\
2019 & {$[47-56]$} & $(n=10)$ \\
2020 & {$[57-61]$} & $(n=5)$ \\
2021 & {$[62]$} & $(n=1)$ \\
\hline
\end{tabular}

As can be observed, the highest number of publications was in $2019(n=10)$, followed by $2018(n=9)$ and $2017(n=8)$. On the other hand, a slight fall in the number of publications was witnessed in $2020(n=5)$.

\subsubsection{Context of the Studies}

As regards contextualisation, specifically the university studies where the research analysed was carried out, a cross-cutting approach prevails; most of it was carried out in various faculties $(n=15)$. However, we found $22 \%$ of studies carried out in faculties of Education $(n=9)$. This was followed by studies related to Computer Science $(n=5)$ and Health Sciences $(n=4)$ (see Figure 2). 


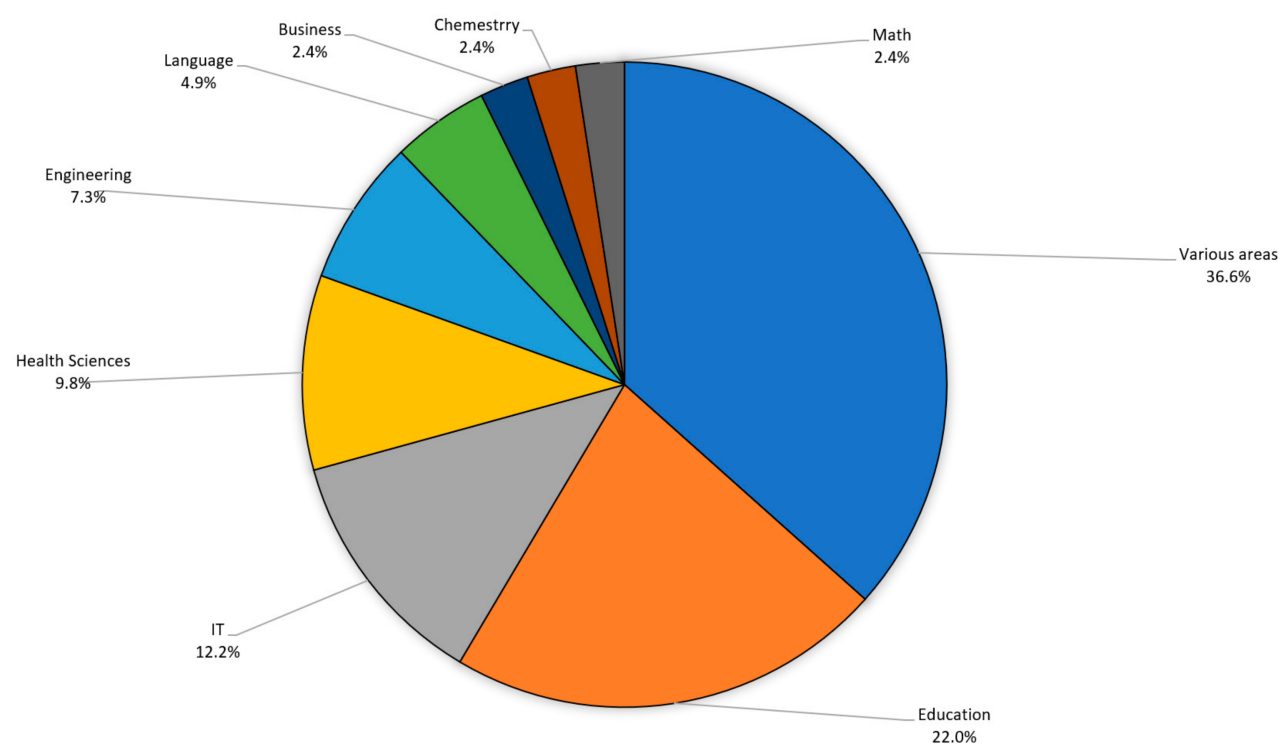

Figure 2. Areas of knowledge.

\subsubsection{Research Methodology}

As regards the methodological perspective adopted in the various studies, the quantitative approach is the most prevalent $(n=23)$. Mixed studies amounted to slightly less than a third $(n=14)$, and only four were carried out using a qualitative methodological option. Figure 3 shows their distribution in graphic form.

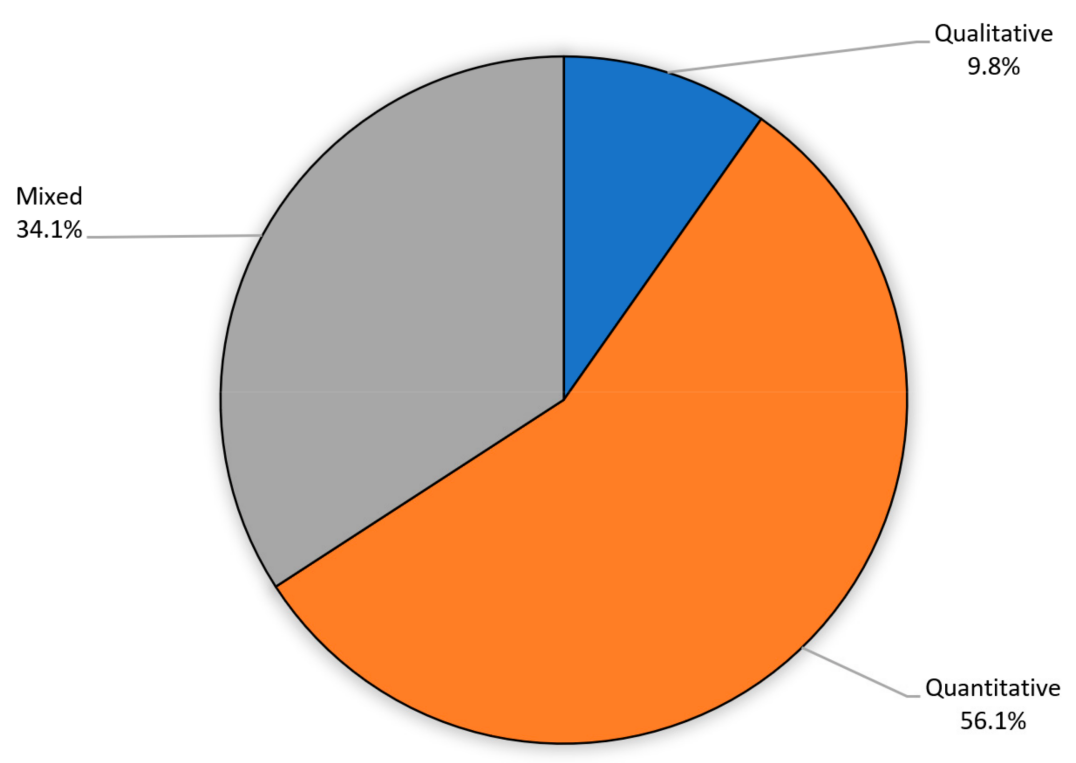

Figure 3. Research methodology.

The vast majority of the studies analysed use the questionnaire as the data collection tool. This tool is used by both quantitative and qualitative studies, in this case, using open-ended questions, where the topics of study may be expressed without restrictions. Specifically, of the 41 papers analysed, a total of 22 used a questionnaire to collect information. We may also observe that quite a few of the studies $(n=10)$ used the standardised MSLQ questionnaire or a variant to be able to verify the students' level of self-regulation. As regards qualitative studies, they adopted varied data collection techniques, such as self-reporting, interviews, document analysis or a focus group. 


\subsubsection{Technological Elements or Environments Used}

The technological resources analysed in the research papers were grouped into five broad categories: LMS $(n=29)$ (either standard ones or made by the institutions themselves); learning environments designed with specific characteristics as tutoring systems, adaptive, created to cover the specific needs of patients (in university degrees in health) or a virtual reality environment $(n=5)$; application, specific web 2.0 programs $(n=3)$; e-portfolio $(n=2)$; MOOC $(n=2)$ (Figure 4).

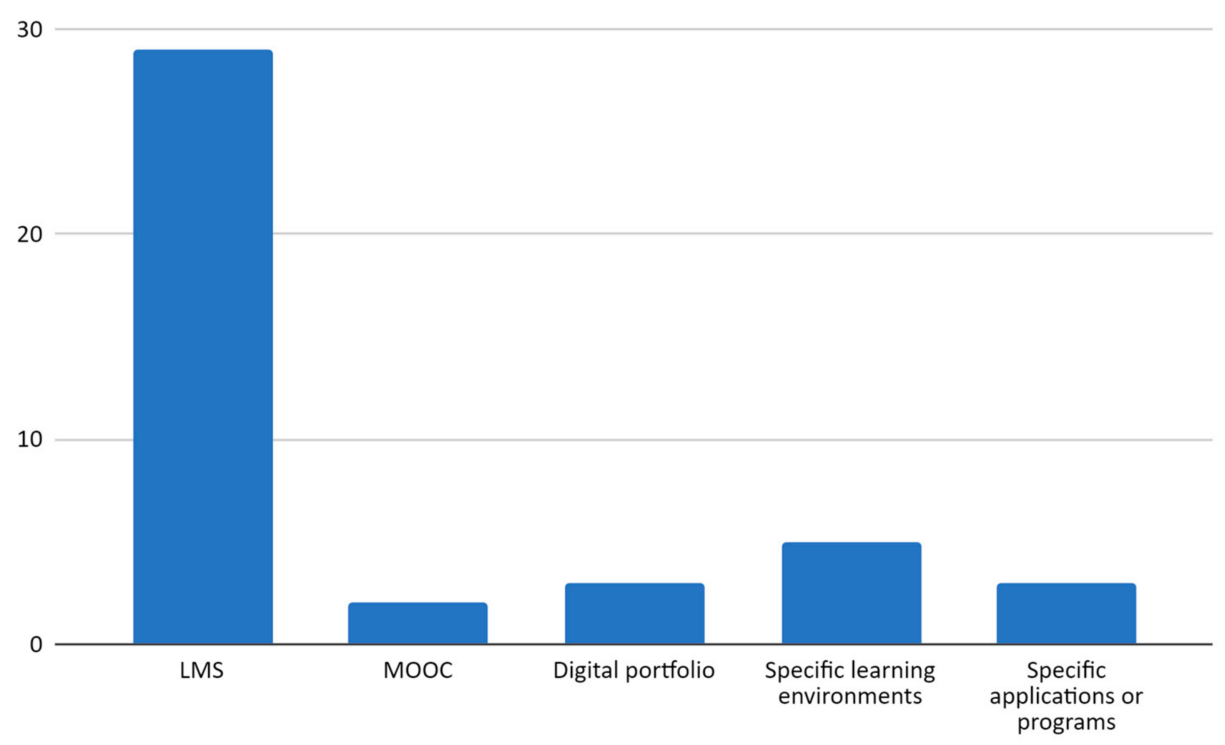

Figure 4. Technological resources and strategies used to promote self-regulation.

\subsubsection{Self-Regulation Models}

The research initiated by Zimmerman [11] was the forerunner in this field. The concept of self-regulation is understood as a process consisting of self-generated thoughts, emotions and actions planned cyclically to achieve personal goals [14]. The analysis shows its theoretical influence on the development of the papers, along with other models that have arisen from it (Figure 5). However, the documents mention more than one conceptualisation to support the development of the research.

Firstly, it is necessary to say that the starting framework, in most papers, is not limited to a single author or conceptualisation. The theoretical perspective most often mentioned in the papers is the cyclical model proposed by Zimmerman [14] and its later revision [63] $(n=25)$. According to this concept, self-regulation is organised around three phases: anticipation, execution and self-reflection. Below is the model created by Pintrich [9] $(n=15)$ based on four phases aimed at self-regulation of learning: anticipation, monitoring, control and reflection. Both models represent the highest share of the papers analysed. However, there are others, such as Bandura's social-cognitive model [64] $(n=8)$, the model proposed by Winne and Hadwin [65] $(n=7)$ and Boekaerts's heuristic model $[6,66](n=5)$.

Normally, these models offer the basis required by way of theoretical support for the studies considered. Each of them implies a series of inherent presuppositions, though these elements are not always made explicit. 


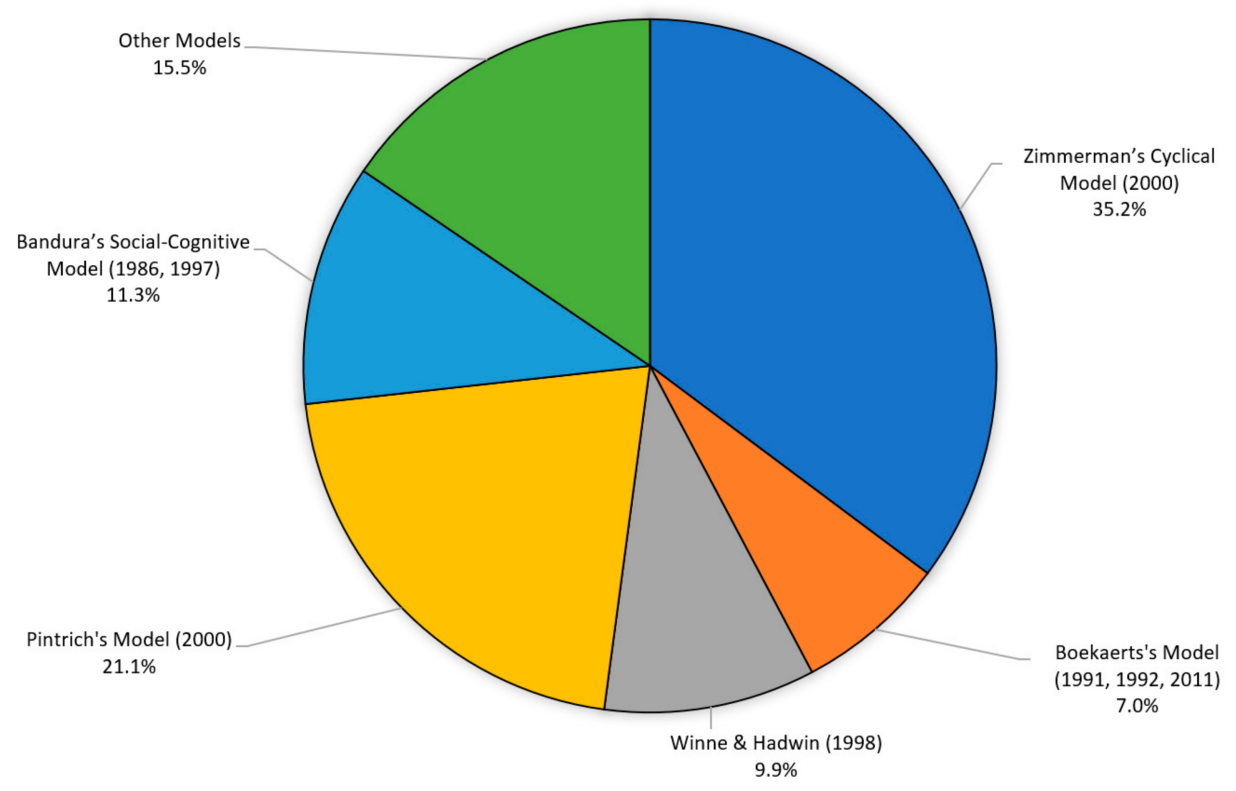

Figure 5. Self-regulation models.

The following table (Table 3) relates, in summary form, the factors that are clearly expressed in the research: technology and SRL level assessment strategies. It should be noted that the table does not seek to establish any kind of relationship but rather simply to illustrate the findings in an orderly manner in the papers analysed in descriptive form.

Table 3. Self-regulation, technology and assessment models.

\begin{tabular}{|c|c|c|}
\hline Reference Models & $\begin{array}{l}\text { Technological Resources to Promote } \\
\text { Self-Regulation }\end{array}$ & SRL Assessment Strategies \\
\hline Zimmerman's cyclical model (2000) & $\begin{array}{c}\text { Infographics } \\
\text { Virtual learning environments (LMS) } \\
\text { MOOC } \\
\text { QR codes } \\
\text { Portfolio }\end{array}$ & $\begin{array}{c}\text {-Questionnaires } \\
\text { Scales } \\
\text { Interviews with the students } \\
\text { Interview with the teaching staff } \\
\text { Document analysis } \\
\text {-Portfolios }\end{array}$ \\
\hline $\begin{array}{l}\text { Bandura's social-cognitive model } \\
\qquad(1986,1997)\end{array}$ & $\begin{array}{c}\text { Virtual learning environments (LMS) } \\
\text { Tutorials } \\
\text { PLE } \\
\text { Virtual reality }\end{array}$ & $\begin{array}{c}\text { Scales } \\
\text { Questionnaires } \\
\text { Portfolios }\end{array}$ \\
\hline Boekaerts's Heuristic Model $(1995,1996)$ & Virtual learning environments (LMS) & Questionnaires \\
\hline Winne and Hadwin (1998) & $\begin{array}{l}\text { Virtual learning environments (LMS) } \\
\text { Intelligent tutoring system }\end{array}$ & $\begin{array}{l}\text { Questionnaires } \\
\text { Scales }\end{array}$ \\
\hline $\begin{array}{l}\text { Pintrich Model } \\
\text { (2000) }\end{array}$ & $\begin{array}{l}\text { Virtual learning environments (LMS) } \\
\text { MOOC }\end{array}$ & $\begin{array}{l}\text { Questionnaires } \\
\text { Scales }\end{array}$ \\
\hline
\end{tabular}

The LMSs adopted by the institution are usually the most-studied technological factor aimed at making it easier for students to achieve their aims and to achieve selfregulation. That may be due, firstly, to their extensive presence in universities; also, and as a result thereof, the teaching staff and students' familiarity with and knowledge of the environments and their tools would be determining factors. At all events, a large share of the studies reviewed, albeit they discuss some technological resources, do not analyse in detail the involvement of these elements in the various aspects of self-regulation nor in how they are used or may affect regulation of learning. 


\section{Conclusions}

The review and analysis undertaken established that the topic has been progressively gaining interest, which is evidenced by an increase in the number of publications that relate the use of certain technological elements or environments as factors that may potentially favour self-regulated learning $(n=41)$, albeit there was a slight fall in the last year analysed.

The theoretical approaches adopted in the studies mostly refer to Zimmerman's cyclical model [14] and that proposed by Pintrich [9] and their derivations. Both models conceive students as active agents throughout the teaching-learning process.

The most prevalent technological factor, in analysing the models underlying the various studies, is the LMS adopted by the institution. This may be due to its becoming ubiquitous in universities and the degree of familiarity and knowledge of the teaching staff and students of the environments and their tools. The paradigmatic example is the platform Moodle which, according to Martínez-Sarmiento and Gaeta [49], includes the elements necessary to promote the students' self-regulated learning.

As regards the context where the studies analysed were carried out, those adopting a cross-cutting approach prevail and were carried in different university degrees. That may suggest a desire to seek to account for a phenomenon that inspires similar interest in research in different areas of knowledge. However, within what might be expected, studies carried out with Education students are also quite abundant, since self-regulation of learning is a frequent topic of study in this area of knowledge.

In the review, case studies were located that show the importance of self-regulation in students as a form of individual and group growth, introducing remote strategies [59].

Self-regulation in technology-enriched learning environments (TELE) presents many challenges, particularly in relation to students' commitment, motivation, social connection and feedback. However, insufficient papers were found that are concerned with studying how various technological elements are related to said aspects.

Finally, we believe that the events derived from the health emergency caused by COVID-19 have caused an increase in the use of technological environment as a teachinglearning environment, which will surely entail an increase in studies related to the topic of study treated.

Author Contributions: Conceptualization, J.S.; data analysis, S.V. and S.U.; funding acquisition, J.S.; methodology, J.S., S.U. and S.V.; conclusions, J.S., S.U. and S.V.; writing—original draft, J.S., S.U. and S.V. All authors have read and agreed to the published version of the manuscript.

Funding: This research was funded by FEDER/Spanish Ministry of Science and Innovation/State Research Agency/Grant number EDU2017-84223-R.

Institutional Review Board Statement: Not applicable.

Informed Consent Statement: Not applicable.

Data Availability Statement: Data from the desk review can be found at: https://bit.ly/2UBcPqr (accessed on 12 December 2020).

Conflicts of Interest: The authors declare no conflict of interest.

\section{References}

1. Zimmerman, B.J. Theories of Self-Regulated Learning and Academic Achievement: An Overview and Analysis. In Self-Regulated Learning and Academic Achievement; Theoretical Perspectives; Zimmerman, B.J., Shunk, Y.D., Eds.; Lawrence Erlbaum Associates: Mahwah, NJ, USA, 2001; pp. 1-38.

2. Carneiro, R.; Lefrere, P.; Steffens, K. Self-regulated Learning in Technology Enhanced Learning Environments: A European Review. Report of the KALEIDOSCOPE Seed Project: Self-Regulated Learning in Technology Enhanced Learning Environments. 2007. Available online: http://www.lmi.ub.es/taconet/documents/srlinteles3.pdf (accessed on 12 December 2020).

3. Dabbagh, N.; English, M. Using Student Self-Ratings to Assess the Alignment of Instructional Design Competencies and Courses in a Graduate Program. Tech.Trends 2015, 59, 22-31. [CrossRef]

4. Dabbagh, N.; Kitsantas, A. The role of social media in self-regulated learning. Int. J. Web Based Communities 2013, 9, 256. [CrossRef] 
5. Cabero, J. El Aprendizaje Autorregulado Como Marco Teórico Para la Aplicación Educativa de las Comunidades Virtu-Ales y los Entornos Personales de Aprendizaje. Rev. Teoría Educ. Educ. Cult. Soc. Inf. 2013, 14, 133-156. Available online: http:/ / campus.usal.es/ revistas_trabajo/index.php/revistatesi/article/view/10217/10626 (accessed on 20 November 2020).

6. Boekaerts, M. Self-regulated learning: Bridging the gap between metacognitive and metamotivation theories. Educ. Psychol. 1995, 30, 195-200. [CrossRef]

7. Boekaerts, M.; Pintrich, P.R.; Zeidner, M. (Eds.) Handbook of Self-Regulation; Academic Press: San Diego, CA, USA, 2000.

8. Borkowski, J.G.; Chan LK, S.; Muthukrishna, N. A process-oriented model of metacognition: Links between motivation and executive functioning. In Issues in the Measurement of Metacognition; Schraw, G., Impara, J.C., Eds.; Buros Institute of Mental Measurement: Lincoln, NE, USA, 2000; pp. 1-41.

9. Pintrich, P.R. The role of goal orientation in self-regulated learning. In Handbook of Self-Regulation; Boekaerts, M., Pintrich, P.R., Zeidner, M., Eds.; Academic Press: San Diego, CA, USA, 2000.

10. Winne, P.H.; Perry, N.E. Measuring self-regulated learning. In Handbook of Self-Regulation; Boekaerts, M., Pintrich, P.R., Zeidner, M., Eds.; Academic Press: San Diego, CA, USA, 2000.

11. Zimmerman, B.J. A social cognitive view of self-regulated academic learning. J. Educ. Psychol. 1989, 81, 329-339. [CrossRef]

12. Zimmerman, B.J. Becoming a Self-Regulated Learner: An Overview. Theory Pract. 2002, 41, 64-70. [CrossRef]

13. Zimmerman, B.J.; Schunk, D.H. Handbook of Self-Regulation of Learning and Performance; Routledge: New York, NY, USA, 2011.

14. Zimmerman, B.J. Attaining self regulation: A social cognitive perspective. In Handbook of Self-Regulation; Boekaerts, M., Pintrich, P.R., Zeidner, M., Eds.; Academic Press: San Diego, CA, USA, 2000; pp. 13-38.

15. Panadero, E. A Review of Self-regulated Learning: Six Models and Four Directions for Research. Front. Psychol. 2017, 8, 422. [CrossRef]

16. Panadero, E.; Alonso-Tapia, J. ¿Cómo autorregulan nuestros alumnos? Modelo de Zimmerman sobre estrategias de aprendizaje. An. Psicol. 2014, 30, 450-462. [CrossRef]

17. Pham, M.T.; Rajić, A.; Greig, J.D.; Sargeant, J.M.; Papadopoulos, A.; McEwen, S.A. A scoping review of scoping reviews: Advancing the approach and enhancing the consistency. Res. Synth. Methods 2014, 5, 371-385. [CrossRef]

18. Arksey, H.; O’Malley, L. Scoping studies: Towards a methodological framework. Int. J. Soc. Res. Methodol. 2005, 8, 19-32. [CrossRef]

19. Armstrong, R.; Hall, B.J.; Doyle, J.; Waters, E. 'Scoping the scope' of a cochrane review. J. Public Health 2011, 33, 147-150. [CrossRef]

20. Peters, M.D.J.; Godfrey, C.; McInerney, P.; Baldini Soares, C.; Khalil, H.; Parker, D. Chapter 11: Scoping Reviews. Joanna Briggs Institute Reviewer's Manual. 2017. Available online: https:/ / reviewersmanual.joannabriggs.org/ (accessed on 13 October 2020).

21. Moher, D.; Liberati, A.; Tetzlaff, J.; Altman, D.G.; The PRISMA Group. Preferred reporting items for systematic reviews and meta-analyses: The PRISMA statement. PLoS Med. 2009, 6, e1000097. [CrossRef]

22. Duffy, M.C.; Azevedo, R. Motivation matters: Interactions between achievement goals and agent scaffolding for self-regulated learning within an intelligent tutoring system. Comput. Hum. Behav. 2015, 52, 338-348. [CrossRef]

23. Nussbaumer, A.; Hillemann, E.-C.; Gütl, C.; Albert, D. A Competence-based Service for Supporting Self-Regulated Learning in Virtual Environments. J. Learn. Anal. 2015, 2, 101-133. [CrossRef]

24. Chatzara, K.; Karagiannidis, C.; Stamatis, D. Cognitive support embedded in self-regulated e-learning systems for students with special learning needs. Educ. Inf. Technol. 2016, 21, 283-299. [CrossRef]

25. Edelbring, S.; Wahlström, R. Dynamics of study strategies and teacher regulation in virtual patient learning activities: A cross sectional survey. BMC Med. Educ. 2016, 16, 122. [CrossRef]

26. Lee, S.; Barker, T.; Kumar, V.S. Effectiveness of a Learner-Directed Model for e-Learning. Educ. Technol. Soc. 2016, 19, 221-233. Available online: https:/ / drive.google.com/open?id=1zNrVXOyFtuuPT9Ydgc3Nr3uLZxkMH0gX (accessed on 20 November 2020).

27. Ng, E.M. Fostering pre-service teachers' self-regulated learning through self- and peer assessment of wiki projects. Comput. Educ. 2016, 98, 180-191. [CrossRef]

28. Zhu, Y.; Au, W.; Yates, G. University students' self-control and self-regulated learning in a blended course. Internet High. Educ. 2016, 30, 54-62. [CrossRef]

29. Lin, J.-W.; Lai, Y.-C.; Chang, L.-C. Fostering self-regulated learning in a blended environment using group awareness and peer assistance as external scaffolds. J. Comput. Assist. Learn. 2016, 32, 77-93. [CrossRef]

30. Juan, F.; Pardo García, R. El ePortafolio Como Instrumento Para Fomentar la Autorregulación del Aprendizaje. 2016, pp. 1-11. Available online: https:/ /ddd.uab.cat/record/166497 (accessed on 12 December 2020).

31. Yot Domínguez, C.; Gallego Domínguez, C. Fomentar el Aprendizaje Autorregulado con Tecnologías en el Contexto Universitario. Libro de Actas. In Proceedings of the EDUNOVATIC 2016-I Congreso Virtual Internacional de Educación, Innovación y TIC, Madrid, Spain, 14- 16 December 2016; pp. 48-59. Available online: https:/ / dialnet.unirioja.es / servlet/extart?codigo=5792700 (accessed on 20 November 2020).

32. Broadbent, J. Comparing online and blended learner's self-regulated learning strategies and academic performance. Internet High. Educ. 2017, 33, 24-32. [CrossRef]

33. De Bruin, A.B.H.; Kok, E.; Lobbestael, J.; de Grip, A. The impact of an online tool for monitoring and regulating learning at university: Overconfidence, learning strategy, and personality. Metacognition Learn. 2017, 12, 21-43. [CrossRef] 
34. Poitras, E.G.; Doleck, T.; Huang, L.; Li, S.; Lajoie, S.P. Advancing teacher technology education using open-ended learning environments as research and training platforms. Australas. J. Educ. Technol. 2017, 33. [CrossRef]

35. Schlag, M.; Imhof, M. Does Perceived Ease of Use Mitigate Computer Anxiety and Stimulate Self-regulated Learning for Pre-Service Teacher Students? Int. J. High. Educ. 2017, 6, 154. [CrossRef]

36. $\mathrm{Wu}, \mathrm{J} .-\mathrm{Y}$. The indirect relationship of media multitasking self-efficacy on learning performance within the personal learning environment: Implications from the mechanism of perceived attention problems and self-regulation strategies. Comput. Educ. 2017, 106, 56-72. [CrossRef]

37. Blau, I.; Shamir-Inbal, T. Re-designed flipped learning model in an academic course: The role of co-creation and co-regulation. Comput. Educ. 2017, 115, 69-81. [CrossRef]

38. Shyr, W.-J.; Chen, C.-H. Designing a technology-enhanced flipped learning system to facilitate students' self-regulation and performance. J. Comput. Assist. Learn. 2017, 34, 53-62. [CrossRef]

39. Chou, C.-Y.; Lai, K.R.; Chao, P.-Y.; Tseng, S.-F.; Liao, T.-Y. A negotiation-based adaptive learning system for regulating help-seeking behaviors. Comput. Educ. 2018, 126, 115-128. [CrossRef]

40. Rovers, S.F.; Clarebout, G.; Savelberg, H.H.; Van Merrienboer, J.J. Improving student expectations of learning in a problem-based environment. Comput. Hum. Behav. 2018, 87, 416-423. [CrossRef]

41. Pérez, A.; Marín, V.I.; Tur, G. Information Management Tools for the Development of Self-Regulated Learning Skills in Pre-service Teacher Education. Tic. Rev. D'innovació Educ. 2018, 21, 31-39. [CrossRef]

42. Hughes, C.; Costley, J.; Lange, C. The effects of self-regulated learning and cognitive load on beginning to watch and completing video lectures at a cyber-university. Interact. Technol. Smart Educ. 2018, 15, 220-237. [CrossRef]

43. Al-Hatem, A.I.; Masood, M.; Al-Samarraie, H. Fostering Student Nurses' Self-Regulated Learning with the Second Life Environment: An Empirical Study. J. Inf. Technol. Educ. Res. 2018, 17, 285-307. [CrossRef]

44. Broadbent, J.; Fuller-Tyszkiewicz, M. Profiles in self-regulated learning and their correlates for online and blended learning students. Educ. Technol. Res. Dev. 2018, 66, 1435-1455. [CrossRef]

45. Haşlaman, T. Supporting students as self-regulated learners with use of infographics: "How can i learn better?". Elem. Educ. Online 2018, 17, 277-292. [CrossRef]

46. Li, H.; Flanagan, B.; Konomi, S.; Ogata, H. Measuring Behaviors and Identifying Indicators of Self-Regulation in ComputerAssisted Language Learning Courses. Res. Pract. Technol. Enhanc. Learn. 2018, 13, 1-12. [CrossRef]

47. Xie, K.; Hensley, L.C.; Law, V.; Sun, Z. Self-regulation as a function of perceived leadership and cohesion in small group online collaborative learning. Br. J. Educ. Technol. 2017, 50, 456-468. [CrossRef]

48. Lim, L.-A.; Gentili, S.; Pardo, A.; Kovanović, V.; Whitelock-Wainwright, A.; Gašević, D.; Dawson, S. What changes, and for whom? A study of the impact of learning analytics-based process feedback in a large course. Learn. Instr. 2021, 72, 101202. [CrossRef]

49. Martínez-Sarmiento, L.F.; González, M.L.G. Use of Moodle virtual platform for the development of self-regulated learning in university students [Utilización de la plataforma virtual Moodle para el desarrollo del aprendizaje autorregulado en estudiantes universitarios]. Educar 2018, 55, 479. [CrossRef]

50. Bernacki, M.L.; Vosicka, L.; Utz, J.C. Can a brief, digital skill training intervention help undergraduates "learn to learn" and improve their STEM achievement? J. Educ. Psychol. 2020, 112, 765-781. [CrossRef]

51. Manganello, F.; Falsetti, C.; Leo, T. Self-Regulated Learning for Web-Enhanced Control Engineering Education. Educ. Technol. Soc. 2019, 22, 44-58. Available online: https: / www.scopus.com/inward/record.uri?eid=2-s2.0-85063789960\&partnerID=40\&md5=7 c08e85f060e3d343a860908e20d638d (accessed on 12 December 2020).

52. Yick, K.-L.; Yip, J.; Au, S.-C.; Lai, Y.-Y.; Yu, A. Effectiveness of blended learning in the first year of fashion education. Int. J. Fash. Des. Technol. Educ. 2018, 12, 178-188. [CrossRef]

53. Tur, G.; Urbina, S.; Forteza, D. Rubric-based formative assessment in process eportfolio: Towards self-regulated learning. Digit. Educ. Rev. 2019, 35, 18-35. [CrossRef]

54. Nuankaew, W.; Nuankaew, P.; Teeraputon, D.; Phanniphong, K.; Bussaman, S. Perception and Attitude Toward Self-Regulated Learning of Thailand's Students in Educational Data Mining Perspective. Int. J. Emerg. Technol. Learn. 2019, 14, 34-49. [CrossRef]

55. Wang, K.; Zhu, C. MOOC-based flipped learning in higher education: Students' participation, experience and learning performance. Int. J. Educ. Technol. High. Educ. 2019, 16, 1-18. [CrossRef]

56. Cárdenas-Robledo, L.A.; Peña-Ayala, A. A holistic self-regulated learning model: A proposal and application in ubiquitouslearning. Expert Syst. Appl. 2019, 123, 299-314. [CrossRef]

57. Supriyono, Y.; Saukah, A.; Latief, M.A.; Widiati, U.; Suryati, N. EFL Learners' Self-Regulated Learning in a Technol-Ogy-Mediated Language Learning Setting. Int. J. Innov. Creat. Chang. 2020, 10, 270-285. Available online: https://www.scopus.com/inward/ record.uri?eid=2-s2.0-85079655068\&partnerID=40\&md5=4f743149c5954509582d56e8de75e842 (accessed on 12 December 2020).

58. Perez-Alvarez, R.A.; Maldonado-Mahauad, J.; Sharma, K.; Sapunar-Opazo, D.; Perez-Sanagustin, M. Characterizing Learners' Engagement in MOOCs: An Observational Case Study Using the NoteMyProgress Tool for Supporting Self-Regulation. IEEE Trans. Learn. Technol. 2020, 13, 676-688. [CrossRef]

59. MacMahon, S.; Leggett, J.; Carroll, A. Promoting individual and group regulation through social connection: Strategies for remote learning. Inf. Learn. Sci. 2020, 121, 353-363. [CrossRef]

60. Cerezo, R.; Bogarín, A.; Esteban, M.; Romero, C. Process mining for self-regulated learning assessment in e-learning. J. Comput. High. Educ. 2019, 32, 74-88. [CrossRef] 
61. Zheng, J.; Xing, W.; Zhu, G.; Chen, G.; Zhao, H.; Xie, C. Profiling self-regulation behaviors in STEM learning of engineering design. Comput. Educ. 2020, 143, 103669. [CrossRef]

62. Zheng, J.; Huang, L.; Li, S.; Lajoie, S.P.; Chen, Y.; Hmelo-Silver, C.E. Self-regulation and emotion matter: A case study of instructor interactions with a learning analytics dashboard. Comput. Educ. 2021, 161, 104061. [CrossRef]

63. Zimmerman, B.J.; Moylan, A.R. Self-regulation: Where metacognition and motivation intersect. In Handbook of Metacognition in Education; Hacker, D.J., Dunlosky, J., Graesser, A.C., Eds.; Routledge/Taylor \& Francis Group: New York, NY, USA, 2009; pp. 299-315.

64. Bandura, A. Social Foundations of Thought and Action: A Social Cognitive Theory; Prentice-Hall: Englewood Cliffs, NJ, USA, 1986.

65. Winne, P.H.; Hadwin, A.F. Studying as self-regulated learning. In Metacognition in Educational Theory and Practice; Hacker, D.J., Dunlosky, J., Graesser, A.C., Eds.; Routledge: New York, NY, USA, 1998; pp. 291-318.

66. Boekaerts, M. Self-regulated Learning at the Junction of Cognition and Motivation. Eur. Psychol. 1996, 1, 100-112. [CrossRef] 